\title{
From Transitions to Transformation: A Brief Review of the Potential Impacts of COVID-19 on Boosting Digitization, Digitalization, and Systems Thinking in the Built Environment
}

\author{
Ali Cheshmehzangi ${ }^{1,2 *}$ (1) \\ ${ }^{1}$ Department of Architecture and Built Environment, The University of Nottingham Ningbo China, Ningbo, China \\ ${ }^{2}$ The Centre for Sustainable Energy Technologies (CSET), The University of Nottingham Ningbo China, Ningbo, China \\ Email: *Ali.Cheshmehzangi@nottingham.edu.cn
}

How to cite this paper: Cheshmehzangi, A. (2021) From Transitions to Transformation: A Brief Review of the Potential Impacts of COVID-19 on Boosting Digitization, Digitalization, and Systems Thinking in the Built Environment. Journal of Building Construction and Planning Research, 9, 26-39.

https://doi.org/10.4236/jbcpr.2021.91003

Received: December 28, 2020

Accepted: March 13, 2021

Published: March 16, 2021

Copyright $\odot 2021$ by author(s) and Scientific Research Publishing Inc. This work is licensed under the Creative Commons Attribution International License (CC BY 4.0).

http://creativecommons.org/licenses/by/4.0/ (c) (i) Open Access

\begin{abstract}
In a short time, during the early phases of the COVID-19 pandemic outbreak, we managed to shift rapidly to use digital technologies and replace some of our daily operations with virtual modes. This shift happened so instantly and widely that it enables us to argue that the COVID-19 became a valid reason to boost some of the gradual and ongoing transitions towards faster transformations. In this study, we use gray literature to delve into arguments around the boost for digitization, digitalization, and systems thinking in the development of the built environment. This is mostly discussed from the influence of COVID-19 on some of the existing practices or the business-as-usual of the built environment sector. From technological advancement to technology use, these arguments are put forward to discuss what is likely to be the major driver of technological adoption and the shifting paradigms that are yet to be revealed. The study concludes that the current push towards new directions and development pathways are likely to be widely accepted in a shorter time. The findings of this brief study feed into existing arguments on transformative pathways due to the COVID-19 pandemic.
\end{abstract}

\section{Keywords}

Digitization, Digitalization, Information-Based, Systems Thinking,

Development, Built Environment, COVID-19 


\section{Introduction}

For the last two decades, the growing technologies and the growing demand for technologies have made significant but gradual progress in the development of the built environment. From the use of virtual reality applications for the built environment [1] [2] to integrated methods for decision-making processes [3]-[8], we can see gradual progress that is changing our cities and the built environments. To name a few, some of these integration methods indicate simple but effective strategies, such as bike-sharing systems [9], methods of disaster risk reduction [10] or disaster management [11], off-site construction [12], resilience enhancement [13], waste treatment approaches [14], and some that have led to the development of smart city initiatives globally [15]-[20]. Some of these have promoted urban systems design [21], which are utilized for enabling technologies and various techniques [22] [23] [24] in the development of the built environments. Amongst many examples, some of these technologies include Internet of Things (IoT) [25] [26] [27] [28], internet+ platforms [29] [30] [31], the use and the integration of artificial intelligence (AI) [32] and informatics from communication technology views [33] [34] [35], such as big data, the application of cybersecurity [36], algorithm-based methods [37] [38] [39] [40], machine learning (ML) deep learning (DL), cognitive computing and big data analytics [20], automation methods [41], etc. So far, the primary challenges for these have been the integration of the so-called urban innovation through policies [42] [43], adaptability to the use or integration with our existing networks [44], acceptance of information technologies [45], and financing of those high-level technological initiatives [46] that are transformative in many ways.

The opportunities that are discussed above are seen from the perspective of socio-technical transitions [47] [48] as well as effective enhancement of cities [49] [50] or enhancing technologies for cities [51], city management [52] [53], and the operation of the built environment [54]. In all cases, we see transformative opportunities that require a larger demand for progression. One clear thing is that technology provides an opportunity for transformation and structuring of the built environment and the way we develop. In recent months, this has been experienced widely and globally, across multiple scales and multiple progressions. As we face a major global challenge due to the COVID-19 pandemic outbreak, we see a growing demand for such technologies from various perspectives. Hence, this time can be regarded as the push in increasing the demand for such transformative opportunities in the development of the built environment. It is believed that the time has come to elaborate further on the available technologies, tools, and techniques and boost some of these for the future development of the built environments.

By reflecting on this once-in-a-century outbreak event, we could look into the critical position of the available technologies and technological opportunities that have already been changing the practices of the built environment at a gradual pace. Hence, this study aims to reflect on this unique opportunity that is al- 
ready boosting the use of many digital platforms, and some that are happening in the name of safety and security enhancement [55]. This is looked at from three main perspectives of digitization, digitalization, and systems thinking (in sub-sections 2.1 to 2.3 ).

\section{Transition in Development or Faster Transformation?}

The position of information and communication technology (ICT) is recognized as systems of networked infrastructural, technological conditions [56], and development of smart cities [18]. In light of the boosting situation, we are at this stage, the study provides an overview of a faster transformation rather than what was believed to be happening in a gradual transition. The position of innovation, if to be taken from the technological dimension [57] or technological innovation [58] [59], is clear in many of the recent operations that are no longer ad hoc [60] [61] [62] and is become more of the new normals of the practice [55]. The recent adaptability to the business-as-usual practices enabled many sectors to push towards innovative solutions, most of which were highly dependent on technological advancement and the use of technologies [63], new virtual tools, and digital platforms [55]. This is argued as the standpoint for the digital revolution [64], which is mainly based on enabling the technologies during the time of minimized contacts, lockdown, and disruptions across many sectors. During this time, methods of integrating technologies in the built environment, such as the ICT, smart apps, AI, and GIS [55] [65] [66] [67] [68], are perceived as sudden improvements or new development paradigms. Hence, COVID-19 is seen as a major driver of the use of technology [69] as well as technology integration. In the following three sub-sections, we reflect on some of these advancements during the COVID-19 pandemic to date. These are selected based on their influence and impact on the built environment, as well as the growing demand and trends that are already highlighted in the gray literature of the study.

\subsection{Digitization in the Future Development}

The relationship between digital and smartness has been developing since the inception of the smart city concept [70] and much earlier [71]. Sassen [72] debated this as part of the progress in the contemporary city development. As the conversion from analog to digital, digitization in the built environment is mainly used for data processing, storage, and transmission. The push for digital information-based methods is already shaping in the construction and management of buildings as well as for the purpose of infrastructure development, particularly in the development of a smart built environment. The information-based models are also seen to be boosting fast in other sectors in facing the COVID-19 [73] [74] [75] [76], indicating the opportunity to take a faster speed in some other sectors, such as the built environment [77] [78]. The rapidly increasing demand for off-site meetings and construction management procedures of these few months indicates a paradigm shift towards digitized methods that are in- 
formation-based, interactive, and integrated. Initiated from the rapid development of emergency facilities [55], we can see a wider appreciation of information-based approaches that are for long struggled to be adapted in the current practices of construction and the built environment. Hence, we see this boost for information modeling methods [79], enabling the intelligent technologies for better operations [80] and development of integrated building systems [81]. Altogether, the push for a faster process of digitization is just started.

\subsection{Digitalization in the Future Development}

Somehow associated with digitization and as part of digital transformation [82], the overall picture of digitalization is based on the use of digital technologies and their integration in the development of the built environments. This is aimed to change a business model of the built environment sector and towards more off-site and rapid construction modes of development. The same trends are seen across other sectors that include the use of digital data that could include transport and health [83], cost analysis [84], workflow digitalization [85], digital pedagogy [86], as well as the use of IT-enabled services in healthcare [87], and integrated methods. For instance, in development of universal data sharing standards [88], we see progress in revealing the role of digital standardization and communication across cities and regions. Other examples include the successful utilization of digital health datasets [89], contact-tracing apps [90], provision of monitory and controlling measures [55], resource assessment [91], real-time case information [92], and the faster emergence of $\mathrm{AI}$ in detection procedures and towards policy formation [65]. From the rapid and sudden growth of data and digital platforms [55], we can see a growing demean din the use of such technologies in the built environment sector, specifically from the perspectives of urban heath strategies [93], risk assessment [94], transport [83], as well as automation, building regulating, and management perspectives [95]. The reliability of digitalization elements [96] were tested in a way that allowed for more optimized methods of operation. In this regard, the use of big data, and more specifically in the form of integrated methods, will indicate a paradigm shift to further multi-dimensional assessments and collaborative analytical methods on the use of technological strategies that promote digitalization in the built environment.

\subsection{Systems Thinking in the Future Development}

The two earlier areas of digitization and digitalization lead us to the argument of systems thinking methods that are yet to be explored further in the association with the post-COVID-19 development. Nevertheless, the multi-system and multi-sectoral approaches [55] are the ones that suggest boosting future development based on integrated methods and directions. Based on reflexive views, the use of data and reflective learning through systems thinking could help us to respond more effectively to complex problems like a pandemic event. In doing so, we can generate more integrated decision-making tools, like the one developed 
by the World Economic Forum [97] on detecting and assessing the COVID-19 global issues that are based on eight primary areas of 1) the media role, 2) response and recovery, 3) workforce impact, 4) avoiding infection and spread, (5) finding a vaccine, 6) impact on trade, 7) impact on travel, and 8) impact on financial markets. A systems approach is already identified to be an effective approach to prevent and respond to the complexity of COVID-19 [98], which is aimed to enhance collaborative work [55] [99], and towards better containment and management [100]. As the systems thinking idea indicates, the method includes the built environment issues in relation to other sectors, an approach that is likely to help to boost the idea of multi-sectoral mechanisms [55] [101]. In doing so, the emerging systems thinking methods could be more collaborative to take into consideration the complexity of urban systems, construction management, building performances, etc. The emphasis on complex systems and creating reflexive and vertical systems are likely to become trendy in future development. This will not be specific to the built environment but will include the sector in a larger eco-system of various sectors [55].

\section{Summary of Discussions}

Through a rich literature review of already progressing transitions in the built environment sector, this study provides an overview of the potential impacts of COVID-19 on boosting "digitization", "digitalization", and "systems thinking" in the built environment. Serves as an essay review, and not a systematic review, the intention here is to highlight how transitions are or will be developing towards a faster pace of transformations in the built environment sector. However, such envisaged changes may be context-specific and subject to the current status of progress on digitization and digitalization advancements. For digitization, as summarized in Section 2.1, we anticipate faster progress in four areas of 1) "digital and smartness", particularly for the use of digital data in smart city and buildings (e.g., related to health, resilience, and operations); 2) "data processing", particularly in progressive use of digital data collection, collective data assessments, and data monitory; 3) "data storage", in a form that has already shaped experimental examples of smart city development but now towards integrated use of digital data in practices and/or applications; and 4) "digital transmission", specifically for interactive systems, AI-augmented platforms, smart apps, and smart operations. Besides, for digitalization (summarized in Section 2.2), we anticipate earlier transformations towards 1) Digital technologies and their integration in the urban and building systems, especially for data monitory, accessibility, safety, and security; 2) Digital integration, which will include new modes of digital design, digital construction, and digital thinking in the built environment; 3) IT-enabled services, specifically with the use of AI technologies and ICT-mediated platforms for data monitory, assessment, and management; and 4) Digital datasets, which are likely to become more popular for real-time models, sharing platforms, collaborative systems of building optimization and enhanced design and construction 


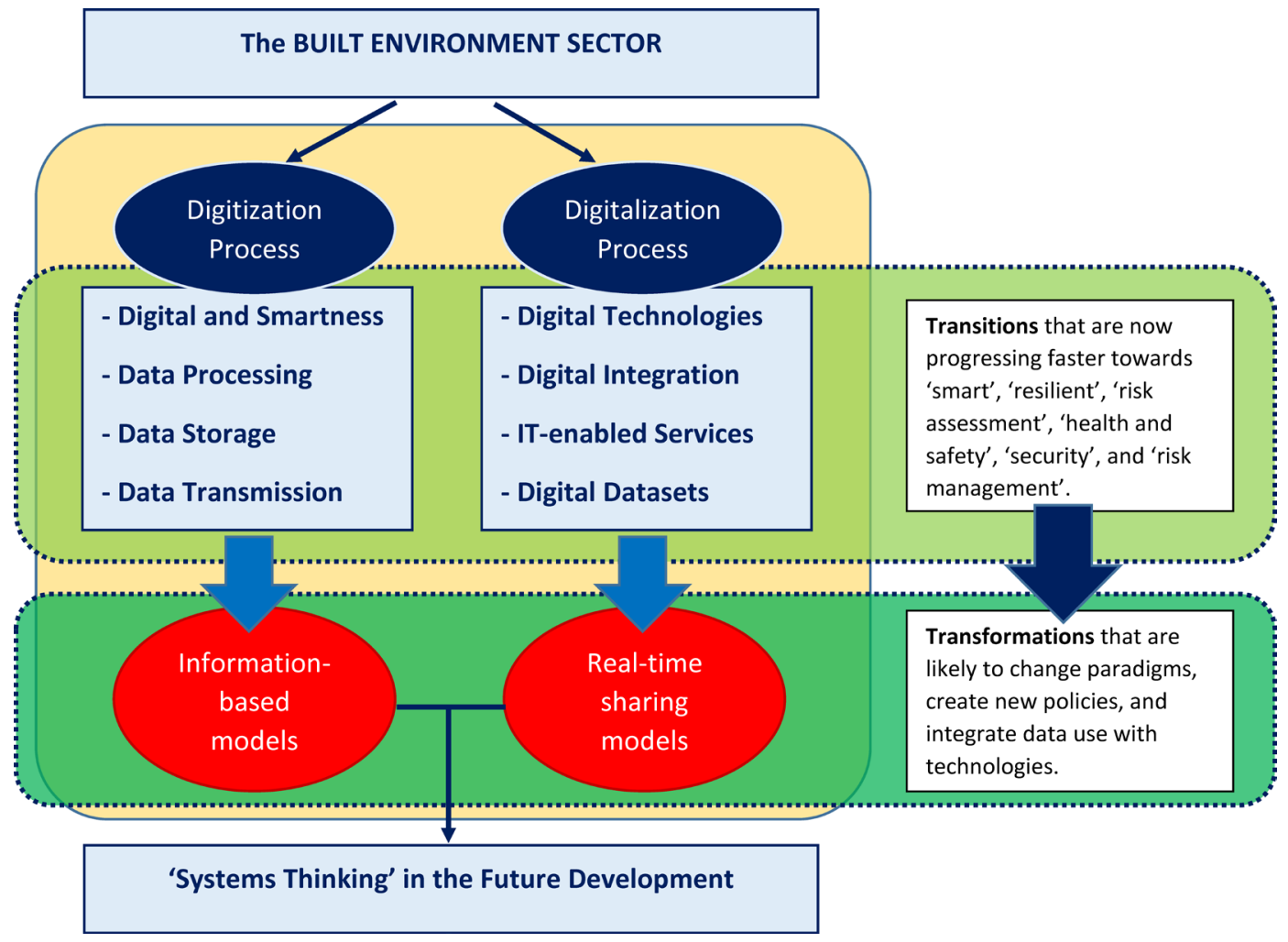

Figure 1. Summary of discussions on boosting digitization, digitalization, and systems thinking in the built environment.

processes. Figure 1 summarizes these potential impacts as they feed into boosting new methods of development in the built environment.

\section{Conclusions}

In all contexts, regardless of the technological advancement levels, the use of technologies in managing COVID-19 and daily operations has been a tangible part of these recent months. There is no doubt that COVID-19 has become a drive to boost the use of technologies in all sectors. From the increasing popularity in e-commerce to the use of virtual and digital platforms for various purposes, new apps, and new communication modes, we see a growing demand for what could be a new chapter in the development of our systems. The built environment sector, being part of this development, would possibly utilize the available toolkits even further and push for new policy formation based on the use of digital technologies. The move from digitization to enhanced digitalization is likely to develop even faster to promote the possibilities for the integration of information-based approaches, and the development of regulations to adopt such methods in common practices. The boost to systems thinking in the built environment is likely to happen from what we described in this study as a multi-sectoral approach. The boost in project management is expected to be much faster than in the architectural design and on-site construction works. The speeding digitalization, however, will be perceived positively and would be 
widely adopted in various regions. This is expected to boost some of the earlier initiatives, such as digital agenda, digital innovation in design, cyber city and cybersecurity, smart built environment, virtual education, and so on. After the current adversities of the pandemic are over, the chance for collaborative digital platforms will boost to a new level that includes more of detection and tracking tools, facial recognition technology, AI applications, future IoT, and digital security systems. In name of safety and security, some of these platforms will be pushed forwarded faster and are expected to be accepted by the general public sooner than anticipated. The role of the built environment will not be minimal as new paradigms are yet to emerge in the near future.

\section{Acknowledgements}

The author would like to thanks the National Natural Science Foundation of China (NSFC) for the provision of funding for project numbers 71950410760 and 71850410544 .

\section{Conflicts of Interest}

The author declares no conflicts of interest regarding the publication of this paper.

\section{References}

[1] Fuchs, P., Moreau, G. and Guitton, P. (2011) Virtual Reality: Concepts and Technologies. CRC Press, Boca Raton. https://doi.org/10.1201/b11612

[2] Zhang, Y., Liu, H., Kang, S.-C. and Al-Hussein, M. (2020) Virtual Reality Applications for the Built Environment: Research Trends and Opportunities. Automation in Construction, 118, Article ID: 103311. https://doi.org/10.1016/j.autcon.2020.103311

[3] Cheshmehzangi, A., Zhu, Y. and Li, B. (2010) Integrated Urban Design Approach: Sustainability for Urban Design. Proceedings for ICRM, Ningbo, January 2010, 241-247.

[4] Kim, H.Y. (2016) Implementing a Sustainable Decision-Making Environment-Cases for GIS, BIM, and Big Data Utilization. Journal of KIBIM, 6, 24-33. https://doi.org/10.13161/kibim.2016.6.3.024

[5] Park, S.-H. and Kim, E. (2016) Middleware for Translating Urban GIS Information for Building a Design Society via General BIM Tools. Journal of Asian Architecture and Building Engineering, 15, 447-454. https://doi.org/10.3130/jaabe.15.447

[6] Zhu, J., Wright, G., Wang, J. and Wang, X. (2018) A Critical Review of the Integration of Geographic Information System and Building Information Modelling at the Data Level. ISPRS International Journal of Geo-Information, 7, 66. https://doi.org/10.3390/ijgi7020066

[7] Wang, H., Pan, Y. and Luo, X. (2019) Integration of BIM and GIS in Sustainable Built Environment: A Review and Bibliometric Analysis. Automation in Construction, 103, 41-52. https://doi.org/10.1016/j.autcon.2019.03.005

[8] Yin, X., Liu, H., Chen, Y. and Al-Hussein, M. (2019) Building Information Modelling for Off-Site Construction: Review and Future Directions. Automation in Construction, 101, 72-91. https://doi.org/10.1016/j.autcon.2019.01.010 
[9] Guo, Y. and He, S.Y. (2020) Built Environment Effect on the Integration of Dockless Bike-Sharing and the Metro. Transportation Research Part D: Transport and Environment, 83, Article ID: 102335. https://doi.org/10.1016/j.trd.2020.102335

[10] Nguyen, V.N., Ginige, K. and Greenwood, D. (2018) Challenges in Integrating Disaster Risk Reduction into the Built Environment-The Vietnam Context. Procedia Engineering, 212, 316-323. https://doi.org/10.1016/j.proeng.2018.01.041

[11] Fan, C., Zhang, C., Yahja, A. and Mostafavi, A. (2019) Disaster City Digital Twin: A Vision for Integrating Artificial and Human Intelligence for Disaster Management. International Journal of Information Management, 56, Article ID: 102049. https://doi.org/10.1016/j.ijinfomgt.2019.102049

[12] Jin, R., Gao, S., Cheshmehzangi, A. and Aboagye-Nimo, E. (2018) A Holistic Review of Off-Site Construction Literature Published between 2008 and 2018. Journal of Cleaner Production, 202, 1202-1219. https://doi.org/10.1016/j.jclepro.2018.08.195

[13] Ransolin, N., Saurin, T.A. and Formoso, C.T. (2020) Integrated Modelling of Built Environment and Functional Requirements: Implications for Resilience. Applied Ergonomics, 88, Article ID: 103154. https://doi.org/10.1016/j.apergo.2020.103154

[14] Wen, Z., Wang, Y. and De Clercq, D. (2016) What Is the True Value of Food Waste? A Case Study of Technology Integration in Urban Food Waste Treatment in Suzhou City, China. Journal of Cleaner Production, 118, 88-96.

https://doi.org/10.1016/j.jclepro.2015.12.087

[15] Nam, T. and Pardo, T.A. (2011) Conceptualizing Smart City with Dimensions of Technology, People, and Institutions. In: Proceedings of the 12 th Annual International Digital Government Research Conference on Digital Government Innovation in Challenging Times, ACM Press, New York, 282. https://doi.org/10.1145/2037556.2037602

[16] Tan-Mullins, M., Cheshmehzangi, A., Chien, S. and Xie, L. (2017) Smart-Eco Cities in China: Trends and City Profiles 2016. University of Exeter, Exeter.

[17] Cecílio, J., Caldeira, F. and Wanzeller, C. (2018) CityMii-An Integration and Interoperable Middleware to Manage a Smart City. Procedia Computer Science, 130, 416-423. https://doi.org/10.1016/j.procs.2018.04.062

[18] Lu, H.-P., Chen, C.-S. and Yu, H. (2019) Technology Roadmap for Building a Smart City: An Exploring Study on Methodology. Future Generation Computer Systems, 97, 727-742. https://doi.org/10.1016/j.future.2019.03.014

[19] Sepasgozar, S.M.E., Hawken, S., Sargolzaei, S. and Foroozanfa, M. (2019) Implementing Citizen Centric Technology in Developing Smart Cities: A Model for Predicting the Acceptance of Urban Technologies. Technological Forecasting and Social Change, 142, 105-116. https://doi.org/10.1016/j.techfore.2018.09.012

[20] Ahad, M.A., Paiva, S., Tripathi, G. and Feroz, N. (2020) Enabling Technologies and Sustainable Smart Cities. Sustainable Cities and Society, 61, Article ID: 102301. https://doi.org/10.1016/j.scs.2020.102301

[21] Yang, P.P.J. and Yamagata, Y. (2020) Chapter 1 Urban Systems Design: Shaping Smart Cities by Integrating Urban Design and Systems Science. In: Yamagata, Y. and Yang, P.P.J., Eds., Urban Systems Design: Creating Sustainable Smart Cities in the Internet of Things Era, Elsevier, Amsterdam, 1-22. https://doi.org/10.1016/B978-0-12-816055-8.00001-4

[22] Balakrishna, C. (2012) Enabling Technologies for Smart City Services and Applications. 2012 Sixth International Conference on Next Generation Mobile Applications, Services and Technologies, Paris, 12-14 September 2012, 223-227. https://doi.org/10.1109/NGMAST.2012.51 
[23] Guelzim, T., Obaidat, M.S. and Sadoun, B. (2016) Introduction and Overview of Key Enabling Technologies for Smart Cities and Homes. In: Obaidat, M.S. and Nicopolitidis, P., Eds., Smart Cities and Homes. Key Enabling Technologies, Morgan Kaufmann, Burlington, 1-16. https://doi.org/10.1016/B978-0-12-803454-5.00001-8

[24] Zahmatkesh, H. and Al-Turjman, F. (2020) Fog Computing for Sustainable Smart Cities in the IoT Era: Caching Techniques and Enabling Technologies-An Overview. Sustainable Cities and Society, 59, Article ID: 102139. https://doi.org/10.1016/j.scs.2020.102139

[25] Evans, D. (2011) The Internet of Things How the Next Evolution of the Internet Is Changing Everything. CISCO White Paper.

https://www.cisco.com/c/dam/en_us/about/ac79/docs/innov/IoT_IBSG_0411FINA L.pdf

[26] Gaur, A., Scotney, B., Parr, G. and McClean, S. (2015) Smart City Architecture and its Applications Based on IoT. Procedia Computer Science, 52, 1089-1094.

https://doi.org/10.1016/j.procs.2015.05.122

[27] Mohanty, S.P., Choppali, U. and Kougianos, E. (2016) Everything You Wanted to Know about Smart Cities: The Internet of Things Is the Backbone. IEEE Consumer Electronics Magazine, 5, 60-70. https://doi.org/10.1109/MCE.2016.2556879

[28] Huang, X. (2020) Multi-Node Topology Location Model of Smart City Based on Internet of Things. Computer Communications, 152, 282-295. https://doi.org/10.1016/j.comcom.2020.01.052

[29] Chen, H. and Liu, Y.H. (2016) The Impact and Planning Reform of "Internet+" to City Space. Planners, No. 4, 1.

[30] Kai, Z. and Bei, T. (2017) Study on Marketing Strategy Model of City Brand in Internet+ Era. The 2017 4th International Conference on Business, Economics and Management (BUSEM2017), Qingdao, 16 November 2017, 99-103.

[31] Tao, M. (2017) Construction and Application of "Internet+ Housing Security" Information System in Wuhan City. Geospatial Information, No. 5, 3.

[32] Anđelković, A. and Bajatović, D. (2020) Integration of Weather Forecast and Artificial Intelligence for a Short-Term City-Scale Natural Gas Consumption Prediction. Journal of Cleaner Production, 266, Article ID: 122096. https://doi.org/10.1016/j.jclepro.2020.122096

[33] Kramers, A, Höjer, M., Lövehagen, N. and Wangel, J. (2014) Smart Sustainable Cities-Exploring ICT Solutions for Reduced Energy Use in Cities. Environmental Modelling \& Software, 56, 52-62. https://doi.org/10.1016/j.envsoft.2013.12.019

[34] Navarro, J.L.A., Ruiz, C.R.L. and Peña, D.N. (2017) The Effect of ICT Use and Capability on Knowledge-Based Cities. Cities Part A, 60, 272-280. https://doi.org/10.1016/j.cities.2016.09.010

[35] Tranos, E. and Ioannides, Y.M. (2020) ICT and Cities Revisited. Telematics and Informatics, 55, Article ID: 101439. https://doi.org/10.1016/j.tele.2020.101439

[36] AlDairi, A. and Tawalbeh, L. (2017) Cyber Security Attacks on Smart Cities and Associated Mobile Technologies. Procedia Computer Science, 109, 1086-1091. https://doi.org/10.1016/j.procs.2017.05.391

[37] Zou, X., Cao, J., Guo, Q. and Wen, T. (2018) A Novel Network Security Algorithm Based on Improved Support Vector Machine from Smart City Perspective. Computers \& Electrical Engineering, 65, 67-78.

https://doi.org/10.1016/j.compeleceng.2017.09.028

[38] Jahani, E., Cetin, K. and Cho, I.H. (2020) City-Scale Single Family Residential 
Building Energy Consumption Prediction Using Genetic Algorithm-Based Numerical Moment Matching Technique. Building and Environment, 172, Article ID: 106667. https://doi.org/10.1016/j.buildenv.2020.106667

[39] Silva, J. Mojica, J., Piñeres, A., Rojas, R., Acosta, S., Garcia Guliany, J. and Steffens Sanabria, E. (2020) Algorithms for the Control of Key Performance Indicators for Smart Cities. Procedia Computer Science, 170, 971-976.

https://doi.org/10.1016/j.procs.2020.03.099

[40] Zhang, W., Wu, Z., Han, G., Feng, Y. and Shu, L. (2020) LDC: A Lightweight Dada Consensus Algorithm Based on the Blockchain for the Industrial Internet of Things for Smart City Applications. Future Generation Computer Systems, 108, 574-582. https://doi.org/10.1016/j.future.2020.03.009

[41] Sozer, H. and Tuysuz, F. (2020) Dynamic Evaluation Method to Increase the Effect of the Automation System on the Building Energy Performance. Journal of Cleaner Production, 253, Article ID: 119811. https://doi.org/10.1016/j.jclepro.2019.119811

[42] Dodgson, M. and Gann, D. (2011) Technological Innovation and Complex Systems in Cities. Journal of Urban Technology, 18, 101-113.

https://doi.org/10.1080/10630732.2011.615570

[43] Praharaj, S., Han, J.H. and Hawken, S. (2018) Urban Innovation through Policy Integration: Critical Perspectives from 100 Smart Cities Mission in India. City, Culture and Society, 12, 35-43. https://doi.org/10.1016/j.ccs.2017.06.004

[44] Yang, Y., Ng, S.T., Xu, F.J. and Skitmore, M. (2018) Towards Sustainable and Resilient High Density Cities through Better Integration of Infrastructure Networks. Sustainable Cities and Society, 42, 407-422. https://doi.org/10.1016/j.scs.2018.07.013

[45] Oliveira, V.A.T. and Santos, G.D. (2019) Information Technology Acceptance in Public Safety in Smart Sustainable Cities: A Qualitative Analysis. Procedia Manufacturing, 39, 1929-1936. https://doi.org/10.1016/j.promfg.2020.01.239

[46] Batabyal, A.A. and Beladi, H. (2019) The Optimal Provision of Information and Communication Technologies in Smart Cities. Technological Forecasting and Social Change, 147, 216-220. https://doi.org/10.1016/j.techfore.2019.07.013

[47] Lex, S.W., Cali, D., Rasmussen, M.K., Bacher, P., Bachalarz, M. and Madsen, H. (2019) A Cross-Disciplinary Path to Healthy and Energy Efficient Buildings. Technological Forecasting and Social Change, 142, 273-284.

https://doi.org/10.1016/j.techfore.2018.07.023

[48] Simmons, G., Giraldo, J.E.D., Truong, Y. and Palmer, M.J. (2018) Uncovering the Link between Governance as an Innovation Process and Socio-Economic Regime Transition in Cities. Research Policy, 47, 241-251. https://doi.org/10.1016/j.respol.2017.11.002

[49] Cheshmehzangi, A. (2016) City Enhancement beyond the Notion of "Sustainable City": Introduction to Integrated Assessment for City Enhancement (iACE) Toolkit. Energy Procedia, 104, 153-158. https://doi.org/10.1016/j.egypro.2016.12.027

[50] Andreani, S., Kalchschmidt, M., Pinto, R. and Sayegh, A. (2019) Reframing Technologically Enhanced Urban Scenarios: A Design Research Model towards Human Centered Smart Cities. Technological Forecasting and Social Change, 142, 15-25. https://doi.org/10.1016/j.techfore.2018.09.028

[51] Curzon, J., Almehmadi, A. and El-Khatib, K. (2019) A Survey of Privacy Enhancing Technologies for Smart Cities. Pervasive and Mobile Computing, 55, 76-95. https://doi.org/10.1016/j.pmcj.2019.03.001

[52] Ding, L.Y., Zhou, Y., Luo, H.B. and Wu, X.G. (2012) Using nD Technology to De- 
velop an Integrated Construction Management System for City Rail Transit Construction. Automation in Construction, 21, 64-73. https://doi.org/10.1016/j.autcon.2011.05.013

[53] Sun, J., Wang, Z. and Li, G. (2018) Measuring Emission-Reduction and Energy-Conservation Efficiency of Chinese Cities Considering Management and Technology Heterogeneity. Journal of Cleaner Production, 175, 561-571. https://doi.org/10.1016/j.jclepro.2017.12.042

[54] Yeh, H. (2017) The Effects of Successful ICT-Based Smart City Services: From Citizens' Perspective. Government Information Quarterly, 34, 556-565. https://doi.org/10.1016/j.giq.2017.05.001

[55] Cheshmehzangi, A. (2020) The City in Need: Urban Resilience and City Management in Disruptive Disease Outbreak Events. Springer, Singapore. https://doi.org/10.1007/978-981-15-5487-2

[56] Graham S. and Marvin S. (2001) Splintering Urbanism: Networked Infrastructures, Technological Mobilities and the Urban Condition. Psychology Press, Hove. https://doi.org/10.4324/9780203452202

[57] Hang, C.C., Yu, D. and Chai, K.-H. (2007) An Exploratory Study on Understanding the Technological Dimension in Disruptive Innovation. The 5 th International Symposium on Management of Technology (ISMOT 07), Hangzhou, 1-3 June 2007, 262-266.

[58] Bairoch, P. (1991) The City and Technological Innovation. In: Higonnet, P.L.R., Landes, D.S. and Rosovsky, H., Eds., Favorites of Fortune, Harvard University Press, Cambridge, 159-176.

[59] Goi, C.-L. (2017) The Impact of Technological Innovation on Building a Sustainable City. International Journal of Quality Innovation, 3, Article No. 6. https://doi.org/10.1186/s40887-017-0014-9

[60] Benghozi, P.-J. (1990) Managing Innovation: From ad hoc to Routine in French Telecom. Organization Studies, 11, 531-554. https://doi.org/10.1177/017084069001100405

[61] Gilmore, T.N. and Krantz, J. (1991) Innovation in the Public Sector: Dilemmas in the Use of Ad Hoc Processes. Journal of Policy Analysis and Management, 10, 455-468. https://doi.org/10.2307/3325326

[62] Bruns, A. (2012) Ad hoc Innovation by Users of Social Networks: The Case of Twitter. International Conference on Indicators and Concepts of Innovation (5th) and Concepts of Innovation NET4SOCIETY Networking Event for Socio-Economic Sciences and Humanities in the 7th Framework Programme, September 2011.

[63] Ting, D.S.-W., Carin, L., Dzau, V. and Wong, T.Y. (2020) Digital Technology and COVID-19. Nature Medicine, 26, 459-461. https://doi.org/10.1038/s41591-020-0824-5

[64] Keesara, S., Jonas, A. and Schulman, K. (2020) Covid-19 and Health Care's Digital Revolution. The New England Journal of Medicine, 382, e82.

https://www.nejm.org/doi/full/10.1056/NEJMp2005835\# https://doi.org/10.1056/NEJMp2005835

[65] Allam, Z., Dey, G. and Jones, D.S. (2020) Artificial Intelligence (AI) Provided Early Detection of the Coronavirus (COVID-19) in China and Will Influence Future Urban Health Policy Internationally. AI, 1, 156-165. https://doi.org/10.3390/ai1020009

[66] Hopman, J., Allegranzi, B. and Mehtar, S. (2020) Managing COVID-19 in Low- and Middle-Income Countries. JAMA, 323, 1549-1550.

https://doi.org/10.1001/jama.2020.4169 
[67] Shaw, R., Kim, Y.-K. and Hua, J. (2020) Governance, Technology and Citizen Behavior in Pandemic: Lessons from COVID-19 in East Asia. Progress in Disaster Science, 6, Article ID: 100090. https://doi.org/10.1016/j.pdisas.2020.100090

[68] Zhou, C., Su, F., Pei, T., Zhang, A., et al. (2020) COVID-19: Challenges to GIS with Big Data. Geography and Sustainability, 1, 77-87. https://doi.org/10.1016/j.geosus.2020.03.005

[69] Zeng, Z., Chen, P.-J. and Lew, A.A. (2020) From High-Touch to High-Tech: COVID-19 Drives Robotics Adoption. Tourism Geographies, 22, 724-734. https://doi.org/10.1080/14616688.2020.1762118

[70] Jucevicius, R., Patašiene, I. and Patašius, M. (2014) Digital Dimension of Smart City: Critical Analysis. Procedia Social and Behavioral Sciences, 156, 146-150. https://doi.org/10.1016/j.sbspro.2014.11.137

[71] Läpple, D. (2001) City and Region in an Age of Globalisation and Digitization. German Journal of Urban Studies, 40, 13-34.

[72] Sassen, S. (1991) The Global City. Wiley, New York.

[73] Ceylan, Z. (2020) Estimation of COVID-19 Prevalence in Italy, Spain, and France. Science of the Total Environment, 729, Article ID: 138817. https://doi.org/10.1016/j.scitotenv.2020.138817

[74] Kumar, A., Gupta, P.K. and Srivastava, A. (2020) A Review of Modern Technologies for Tackling COVID-19 Pandemic. Diabetes \& Metabolic Syndrome: Clinical Research \& Reviews, 14, 569-573. https://doi.org/10.1016/j.dsx.2020.05.008

[75] Nguyen, V.N., Strnad, O., Klein, T., Luo, D., Alharbi, R., Wonka, P. and Viola, I. (2020) Modeling in the Time of COVID-19: Statistical and Rule-Based Mesoscale Models. https://doi.org/10.1109/TVCG.2020.3030415

[76] Rahim, H.U., Rahim, T. and Rahim, A.U. (2020) COVID-19 and the Following Lock-Downs: Is This Will Be a Rest Button for the Ecosystem? https://ssrn.com/abstract=3588524or

[77] Li, L., Zhang, Q., Wang, X., Zhang, J., Wang, T., Gao, T.-L., Duan, W., Tsoi, K.K.-F. and Wang, F.Y. (2020) Characterizing the Propagation of Situational Information in Social Media during Covid-19 Epidemic: A Case Study on Weibo. IEEE Transactions on Computational Social Systems, 7, 556-562. https://doi.org/10.1109/TCSS.2020.2980007

[78] Wang, L., Li, J., Guo, S., Xie, N., Yao, L., Cao, Y. and Ji, J. (2020) Real-Time Estimation and Prediction of Mortality Caused by COVID-19 with Patient Information Based Algorithm. Science of the Total Environment, 727, Article ID: 138394. https://doi.org/10.1016/j.scitotenv.2020.138394

[79] Siountri, K., Skondras, E. and Vergados, D.D. (2020) Developing Smart Buildings Using Blockchain, Internet of Things, and Building Information Modeling. International Journal of Interdisciplinary Telecommunications and Networking (IJITN), 12, 1-15. https://doi.org/10.4018/IJITN.2020070101

[80] Zhou, Y., Wang, L., Ding, L. and Tang, Z. (2020) Intelligent Technologies Help Operating Mobile Cabin Hospitals Effectively Cope with COVID-19. Frontiers of Engineering Management, 7, 459-460. https://doi.org/10.1007/s42524-020-0113-5

[81] Renggli, A.G. (2020) Does COVID-19 Lead to the Demand for Innovative Hospitals. Gordan Kucan M.Sc. in Integrated Building Systems, ETH, 26.05. 2020.

[82] Zhao, M., Liao, H.T. and Sun, S.P. (2020) An Education Literature Review on Digitization, Digitalization, Datafication, and Digital Transformation. In: 6th International Conference on Humanities \& Social Science Research, Atlantis Press, Paris, 
302-306. https://doi.org/10.2991/assehr.k.200428.065

[83] Musselwhite, C., Avineri, E. and Susilo, Y. (2020) Editorial JTH 16-The Coronavirus Disease COVID-19 and Implications for Transport and Health. Journal of Transport \& Health, 16, Article ID: 100853.

https://doi.org/10.1016/j.jth.2020.100853

[84] Makridis, C.A. and Hartley, J.S. (2020) The Cost of COVID-19: A Rough Estimate of the 2020 US GDP Impact. https://doi.org/10.2139/ssrn.3570731 https://www.mercatus.org/system/files/makridis-cost-covid-19-mercatus-v1.pdf

[85] Zhai, Y., Wang, Y., Zhang, M., Gittell, J.H., Jiang, S., Chen, B., et al. (2020) From Isolation to Coordination: How Can Telemedicine Help Combat the Covid-19 Outbreak? https://doi.org/10.1101/2020.02.20.20025957

[86] Crawford, J., Butler-Henderson, K., Rudolph, J. and Glowatz, M. (2020) COVID-19: 20 Countries' Higher Education Intra-Period Digital Pedagogy Responses. Journal of Applied Teaching and Learning (JALT), 3, 1-20.

https://doi.org/10.37074/jalt.2020.3.1.7

[87] Yan, A., Zou, Y. and Mirchandani, D.A. (2020) How Hospitals in Mainland China Responded to the Outbreak of COVID-19 Using IT-Enabled Services: An Analysis of Hospital News Webpages. Journal of the American Medical Informatics Association, 27, 991-999. https://doi.org/10.1093/jamia/ocaa064

[88] Allam, Z. and Jones, D.S. (2020) On the Coronavirus (COVID-19) Outbreak and the Smart City Network: Universal Data Sharing Standards Coupled with Artificial Intelligence (AI) to Benefit Urban Health Monitoring and Management. Healthcare, 8, 46. https://doi.org/10.3390/healthcare8010046

[89] McCall, B. (2020) COVID-19 and Artificial Intelligence: Protecting Health-Care Workers and Curbing the Spread. The Lancet Digital Health, 2, e166-e167. https://doi.org/10.1016/S2589-7500(20)30054-6

[90] McCall, B. (2020) Shut Down and Reboot-Preparing to Minimise Infection in a Post-COVID-19 Era. The Lancet Digital Health, 2, e293-e294. https://doi.org/10.1016/S2589-7500(20)30103-5

[91] Ji, Y., Ma, Z., Peppelenbosch, M.P. and Pan, Q. (2020) Potential Association between COVID-19 Mortality and Health-Care Resource Availability. The Lancet Global Health, 8, e480. https://doi.org/10.1016/S2214-109X(20)30068-1

[92] Pan, X.B. (2020) Application of Personal-Oriented Digital Technology in Preventing Transmission of COVID-19, China. Irish Journal of Medical Science (1971-), 189, 1145-1146. https://doi.org/10.1007/s11845-020-02215-5

[93] Capolongo, S., Rebecchi, A., Buffoli, M., Letizia, A., Carlo, S., Fara, G.M. and Daniela, D.A. (2020) COVID-19 and Cities: from Urban Health Strategies to the Pandemic Challenge. A Decalogue of Public Health Opportunities. Acta Biomedica, 91, 13-22.

[94] Krause, N.M., Freiling, I., Beets, B. and Brossard, D. (2020) Fact-Checking as Risk Communication: The Multi-Layered Risk of Misinformation in Times of COVID-19. Journal of Risk Research, 23, 1052-1059. https://doi.org/10.1080/13669877.2020.1756385

[95] Radanliev, P., De Roure, D. and Van Kleek, M. (2020) Digitalization of COVID-19 Pandemic Management and Cyber Risk from Connected Systems. https://doi.org/10.2139/ssrn.3604825

[96] Ülkeryıldız, E. (2020) Transformation of Public and Private Spaces: Instrumentality of Restrictions on the Use of Public Space during COVID 19 Pandemic. International Conference of Contemporary Affairs in Architecture \& Urbanism, Vol. 6, 8. 
https://doi.org/10.38027/N192020ICCAUA316394

[97] World Economic Forum (2020) Global Issue: COVID-19. https://intelligence.weforum.org/topics/a1G0X000006O6EHUA0?tab=publications

[98] Bradley, D.T., Mansouri, M.A., Kee, F., et al. (2020) A Systems Approach to Preventing and Responding to COVID-19. EClinical Medicine, 21, Article ID: 100325. https://doi.org/10.1016/j.eclinm.2020.100325

[99] Laupacis, A. (2020) Working Together to Contain and Manage COVID-19. CMAJ, 192, E340-E341. https://doi.org/10.1503/cmaj.200428

[100] Rambihar, V.S. (2020) Chaos, Complexity and Systems Thinking to Contain and Manage COVID-19, CMAJ.

https://www.cmaj.ca/content/chaos-complexity-and-systems-thinking-contain-andmanage-covid-19

[101] Cheshmehzangi, A. (2020) COVID-19 and Household Energy Implications: What Are the Main Impacts on Energy Use? Heliyon, 6, e05202.

https://doi.org/10.1016/j.heliyon.2020.e05202 